\title{
Exopolysaccharides produced by Lactobacillus strains suppress HT-29 cell growth via induction of G0/G1 cell cycle arrest and apoptosis
}

\author{
WEI DI ${ }^{1}$, LANWEI ZHANG ${ }^{1,2}$, HUAXI YI $^{2}$, XUE HAN $^{1}$, YINGCHUN ZHANG ${ }^{1}$ and LIANG XIN $^{1}$ \\ ${ }^{1}$ Department of Food Science and Engineering, School of Chemistry and Chemical Engineering, Harbin Institute \\ of Technology, Harbin, Heilongjiang 150090; ${ }^{2}$ Functional Dairy and Probiotics Engineering Laboratory, College \\ of Food Science and Engineering, Ocean University of China, Qingdao, Shandong 266003, P.R. China
}

Received November 22, 2017; Accepted July 4, 2018

DOI: $10.3892 / 01.2018 .9129$

\begin{abstract}
In the present study, the effects of exopolysaccharides (EPS) from nine Lactobacillus strains with a high degree of bio-activity on human colon cancer cell line HT-29 were studied. The extracellular polymeric substances from 4 strains, namely K11, M5, SB27 and X12, displayed desirable anti-proliferative activity against HT-29 cells. Crude and acidic EPS were purified from the 4 strains and the inhibitory effects were further investigated. The crude and acidic EPS from these 4 strains exerted anti-proliferation effects on HT-29 cells in a dose-dependent manner but were nontoxic to Vero cells. Treatment with EPS significantly induced G0/G1 cell cycle arrest and apoptosis of HT-29 cells. Hoechst 33258 staining of acidic EPS-treated HT-29 cells revealed different degrees of morphological changes within the nucleus and the formation of apoptotic bodies. Caspase-3 activity was markedly upregulated in HT-29 cells following treatment with acidic EPS. In addition, acidic EPS from the SB27 strain demonstrated the most robust inhibitory effect on HT-29 cells. The results of the present study suggest that as an inducer of apoptosis EPS has the potential to be applied in the treatment of colorectal cancer.
\end{abstract}

\section{Introduction}

Colorectal cancer is one of the leading causes of cancer-related deaths among men and women, causing approximately 1.4 million new cases and more than 0.5 million deaths per year worldwide (1). Its onset is insidious, often without any obvious

Correspondence to: Dr Lanwei Zhang, Department of Food Science and Engineering, School of Chemistry and Chemical Engineering, Harbin Institute of Technology, 73 Huanghe Road, Nangang, Harbin, Heilongjiang 150090, P.R. China

E-mail: z_1_w_0527@163.com

Key words: anti-proliferation, cell cycle, apoptosis, exopolysaccharides, HT-29 cell, Lactobacillus strains clinical manifestations (2). Several factors were responsible for the development of colon cancer $(3,4)$. The accumulation of mutations in certain protooncogenes and tumor suppressor genes might result in cacer initiation (5). Dietary factors as well as lifestyle have been considered to play a major role in its incidence (6,7). Diet with high fat and low carbohydrate can increase the possibility of occurrence of colon cancer. In particular, consumption with red meat and processed meats, highly refined grains and starches, and sugars is related to rising risk of colon cancer (8).

Lactic acid bacteria (LAB) are commonly known as a kind of probiotics which are facultative anaerobes and widely exist in human intestine and have been reported to possess many useful properties, including immune-modulatory, anti-inflammatory, anti-oxidant and anti-proliferative activity (9). Although recent studies have revealed that desirable biological activity of LAB can be achieved by using living or dead bacteria $(10,11)$, exopolysaccharides (EPS) produced by LAB have particularly received intensive interests for their potential as valuable compounds and in health applications (12). EPS is generally related to all forms of polysaccharides found outside the microbial cell wall. Moreover, EPS represents one of the most important functional components of LAB metabolic products (13), which have been reported to exerted several physiological functions such as immunoregulatory effects (14), anti-oxidant activities (15), anti-hypertensive effects (16) and antitumor activities (17). Among them, antitumor activity has particularly received intensive interest due to the growing number and the high mortality of patients suffered from cancer. Though the antitumor agents used currently in chemotherapy practice possess strong activity, many doubts have raised about their safety and side effects (18) that the public attention has transferred to identification of antitumor agents from natural sources (19). Whether EPS from LAB could be served as an ideal substitute to the synthetic antitumor agents from the safe natural sources has been investigated by a large number of studies (14,17,20-22). However, most of them focused on the EPS produced only by a single LAB strain. Lactobacillus is one of the most notable strains of the LAB group and also commonly used in dairy product fermentation and as probiotic $(23,24)$. The primary aim of this study was 
to investigate the effects of EPS from different Lactobacillus strains, which were facultative anaerobes and showed activity in large intestine (25-27), on a mostly used colon cancer cell line called HT-29. The potential application as an anticancer agent was further discussed.

\section{Materials and methods}

Strains and culture conditions. Nine Lactobacillus strains with high bio-activity, namely $L$. casei X11, L. casei X12, L. casei $\mathrm{K} 11$, L. casei J5, L. rhamnosus $\mathrm{J} 10$, L. casei $\mathrm{M} 5, L$. casei M23, L. rhamnosus IN4125, and L. casei SB27 were choosen based on previous researches $(25,26,28)$. Among them, Lactobacillus IN4125 was isolated from infant faeces; Lactobacillus $\mathrm{J} 5$ and $\mathrm{J} 10$ were isolated from fermented foods in Gansu Province; Lactobacillus M5 and M23 were isolated from Koumiss in Sinkiang; Lactobacillus X11 and X12 were isolated from Cheese in Sinkiang; Lactobacillus K11 was isolated from Kefir in Tibet.

L. rhamnosus GG (LGG, ATCC53103) was used as reference strain, which is a probiotic of human origin and commercially exploited to help maintain a 'good balance' of bacteria in the human intestines by preventing the growth of harmful bacteria $(29,30)$. Stock culture of all Lactobacillus strains was maintained at $-80^{\circ} \mathrm{C}$ in freeze-dried $12.5 \%$ skim milk containing $2.5 \%$ glycerol. All strains were subcultured twice at $37^{\circ} \mathrm{C}$ for $24 \mathrm{~h}$ prior to use in the experiments in $12.5 \%$ sterilized skim milk medium under anaerobic conditions.

Colon cancer cell culture. The human colon cancer cell line, HT-29, was obtained from the Cancer Institute of the Chinese Academy of Medical Science (Beijing, China). HT-29 cells were grown in RPMI-1640 medium (Thermo Fisher Scientific, Inc., Waltham, MA, USA) containing 10\% FBS (Gibco; Thermo Fisher Scientific, Inc.). The cells were incubated in $25 \mathrm{~cm}^{2}$ flasks at $37^{\circ} \mathrm{C}$ in a humidified atmosphere of 95\% filtered air and $5 \% \mathrm{CO}_{2}$ in a $\mathrm{CO}_{2}$ incubator (HEPA class 100; Thermo Fisher Scientific, Inc.). The medium was changed daily to maintain exponential growth of the cells. Cell counts were assessed by standard procedures of cell counting using a hemacytometer.

Preparation of extracellular polymeric substances and MTT assay. Two hundred mini-liter inoculum was prepared as described by Ai et al with some modifications (31). After an approximately $36 \mathrm{~h}$ incubation period, $\mathrm{pH}$ values of the fermentation broth were decreased to 4.5 and the final fermentation was then boiled for $10 \mathrm{~min}$ at $100^{\circ} \mathrm{C}$ to coagulate the protein and inhibit enzyme activity. After cooling, coagulated proteins and heat-treated bacterial cells were separated by centrifugation $(12,000 \mathrm{x} \mathrm{g}$ for $15 \mathrm{~min}$ at $\left.4^{\circ} \mathrm{C}\right)$. Supernatants of the 10 Lactobacillus strains $(9$ experimental strains and 1 control strain) were filtered by $0.22 \mu \mathrm{m}$ membrane and their $\mathrm{pH}$ was adjusted to 7.4 with $10 \mathrm{M} \mathrm{NaOH}$ to obtain the extracellular polymeric substances as the previous description (32).

MTT [3-(4, 5-dimethylthiazol-2-yl)-2,5-diphenyltetrazolium bromide] assay was used to test the anti-proliferative effects of the EPS which had little effects on noncancerous cells (33-35). Briefly, HT-29 colon cells at a density of $1 \times 10^{5}$ cells per $\mathrm{ml}$ were seeded into 96 -well plates. After $12 \mathrm{~h}$ of incubation, cells were treated with $100 \mu 1$ extracellular polymeric substances and then incubated for $48 \mathrm{~h}$. Negative controls were treated with equal volume of RPMI-1640 medium $(35,36)$. Positive controls were treated with $5 \mu \mathrm{g} / \mathrm{ml}$ daunorubicin $(37,38)$. At the end of each treatment, $10 \mu \mathrm{l}(5 \mathrm{mg} / \mathrm{ml})$ of MTT was added and the tumor cells were inoculated for another $4 \mathrm{~h}$. The liquid was then removed and $100 \mu 1$ DMSO was added to the well. After dissolving of the formed crystal formazan, the absorbance was measured at $570 \mathrm{~nm}$ with an enzyme-linked immunosorbent assay plate reader (BioTek-Eon, Gene Company Limited, USA). Results were displayed as the inhibition rates. All results were transformed into percentages based on their separate controls. Calculation was performed by using the following formula: Inhibition rate $=\{1$-(absorbance in test well $) /($ absorbance in control well)\} $\times 100 \%$.

Extract and purification of EPS. Starter culture was prepared as previously described of inoculum, then batch fermentation was performed in a 5.0L capacity fermentor (Biotech-2002; Bao Xing Bio-Engineering Equipment Co., Ltd, Shanghai, China) at $37^{\circ} \mathrm{C}$ with an inoculum concentration of $3.0 \%$ to obtain the fermented broth (15). Extracellular polymeric substances were obtained as described previously (34). The crude EPS fractions were separated and purified according to procedures described by Lin et al with slight modifications (39). The obtained crude EPS fractions were then lyophilized in a freeze-drier (FD-1C-50; Boyikang, Beijing, China). The acidic EPS was purified by using anion exchange chromatography on a DEAE Sepharose Fast-Flow (GE Healthcare, Chicago, IL, USA) column $(1.6 \times 20 \mathrm{~cm})$ with the $\mathrm{NaCl}$ gradient $(0 \sim 1 \mathrm{M})$ as the elution buffer at a flow rate of $1.0 \mathrm{ml} / \mathrm{min}$. The purified acidic EPS was collected by using a fraction collector with $5 \mathrm{ml}$ per tube. The eluent was assayed for carbohydrate contents by the phenol-sulfuric acid method described by DuBois et al (40). The peak fractions containing polysaccharides were pooled and dialyzed with deionized water every $6 \mathrm{~h}$ for $48 \mathrm{~h}$ and freeze-dried.

Measurement of anti-proliferative effects of EPS. The anti-proliferation activity of crude and acidic EPS on HT-29 cells was measured by using MTT assay as described above. After $12 \mathrm{~h}$ of incubation, cells were treated with EPS at a range of concentrations of 10, 20,100, 200, and $500 \mu \mathrm{g} / \mathrm{ml}$ (41) and then incubated for $48 \mathrm{~h}$. The ultimate treatment concentration was determined as $500 \mu \mathrm{g} / \mathrm{ml}$ in consideration of the solubility of EPS in RPMI-1640 medium being less than $600 \mu \mathrm{g} / \mathrm{ml}$. The cells treated only with RPMI-1640 medium were used as the control. All samples were subjected to polysaccharide concentration test before MTT assay. All concentrations of crude and acidic EPS that tested for their inhibition effect on HT-29 colon cell were compared with the control to calculate the inhibition ratio.

Cell cycle analysis. Measurements of HT-29 cell cycles were performed as described by Liu et al by flow cytometry (FACS Calibur; BD Biosciences, Franklin Lakes, NJ, USA) (42). Like the apoptosis determination procedure, HT-29 cells were 
Table I. Anti-proliferation activity of extracellular polymeric substances isolated from Lactobacillus strains.

\begin{tabular}{lllr}
\hline Strain & \multicolumn{1}{c}{ Origin $^{\mathrm{a}}$} & \multicolumn{1}{c}{ Species } & Inhibitory rate $(\%)$ \\
\hline X11 & Traditional cheese; Sinkiang, China & L. casei & $16.22 \pm 0.40^{\mathrm{c}}$ \\
X12 & Traditional cheese; Sinkiang, China & L. casei & $21.10 \pm 0.98^{\mathrm{c}}$ \\
K11 & Traditional Tibetan kefir; Tibet, China & L. casei & $20.11 \pm 0.36$ \\
J5 & Traditional fermented vegetable juice; Gansu Province, China & L. casei & $5.07 \pm 1.39^{\mathrm{c}}$ \\
J10 & Traditional fermented vegetable juice; Gansu Province, China & L. rhamnosus & $11.07 \pm 1.07^{\mathrm{c}}$ \\
M5 & Traditional koumiss; Sinkiang, China & L. casei & $25.75 \pm 0.63^{\mathrm{c}}$ \\
M23 & Traditional koumiss; Sinkiang, China & L. casei & $10.04 \pm 0.50^{\mathrm{c}}$ \\
IN4125 & Infant feces; W/21 months & L. rhamnosus & $9.66 \pm 0.48^{\mathrm{c}}$ \\
SB27 & Traditional fermented yaks' milk food; Gansu Province, China & L. casei & $35.98 \pm 0.47^{\mathrm{c}}$ \\
LGG $^{\mathrm{b}}$ & ATCC53103 & L. rhamnosus GG & $18.82 \pm 1.01$ \\
\hline
\end{tabular}

${ }^{a}$ The strains were obtained from infant feces and traditional fermented foods. The fermented foods were made by local residents using traditional methods under environmental conditions present in northwestern China (Sinkiang, Tibet and Gansu). ${ }^{\text {b }}$ LGG strain was used as the reference strain. The positive control group was the absorbance of the system treated with extracellular polymeric substances isolated from LGG strain. ${ }^{\mathrm{C}} \mathrm{P}<0.01 \mathrm{vs}$. the positive control group.

seeded onto 6-well plates and treated after $24 \mathrm{~h}$ of incubation with crude or acidic EPS fractions for $48 \mathrm{~h}$. HT-29 cells were trypsinized and washed twice with pro-cooling PBS and fixed in $70 \%$ ethanol at $20^{\circ} \mathrm{C}$ for $1 \mathrm{~h}$. Fixed cells were then washed twice with PBS and re-suspended in $500 \mu \mathrm{l}$ of $0.5 \%$ Triton $\mathrm{X}-100 / \mathrm{PBS}$ at $37^{\circ} \mathrm{C}$ for $30 \mathrm{~min}$ with $1 \mathrm{mg} / \mathrm{ml}$ of RNase A (Sigma-Aldrich; Merck KGaA, Darmstadt, Germany). Cells were stained with $10 \mu \mathrm{l}$ of propidium iodide (PI) solution (BD Biosciences) in the dark and analyzed using a FACS Calibur flow cytometer installed with Cell Quest software (both BD Biosciences) $(43,44)$.

Hoechst 33258 staining. Morphological changes in the nuclear chromatin of HT-29 cells treated with acidic EPS fractions were detected by Hoechst 33258 staining. Cells were cultured in RPMI 1640 medium containing 10\% FBS and seeded onto 6 -well plates with the concentration of $2 \times 10^{6}$ cells/well in $2 \mathrm{ml}$ medium. After $24 \mathrm{~h}$ of incubation, cells were treated with $500 \mu \mathrm{g} / \mathrm{ml}$ acidic EPS fractions for $48 \mathrm{~h}$. Subsequently, the EPS-treated cells were harvested and washed twice with PBS. Then cells were fixed with $4 \%$ paraformaldehyde at $37^{\circ} \mathrm{C}$ for $20 \mathrm{~min}$. After washed twice with PBS, the cells were incubated with $50 \mu \mathrm{g} / \mathrm{ml}$ Hoechst 33258 staining solution for $15 \mathrm{~min}$ at room temperature in the dark followed by wash with PBS for $5 \mathrm{~min}$ and repeated twice. Cells were examined and photographed using the inverted fluorescence microscope (Axio Vert. A1; Zeiss AG, Oberkochen, Germany).

Cell apoptosis by flow cytometry. Measurements of cell apoptosis and necrosis were performed as previously described by Sharma et al (45). Briefly, HT-29 cells were seeded onto 6 -well plates $24 \mathrm{~h}$ and then treated with $500 \mu \mathrm{g} / \mathrm{ml}$ of crude or acidic EPS fractions for $48 \mathrm{~h}$. Then cells were harvested, washed twice with pro-cooling PBS ( $\mathrm{pH}$ 7.4) and resuspended in $100 \mu \mathrm{l}$ binding buffer (BD Biosciences). Annexin V-FITC (5 $\mu$ l Fluorescein isothiocyanate; Ex $488 \mathrm{~nm}$, Em $515 \mathrm{~nm}$ ) and $5 \mu \mathrm{l}$ of PI (Ex $633 \mathrm{~nm}$ ) were added to the solution at room temperature $\left(25^{\circ} \mathrm{C}\right)$ in the dark. The cells were supplemented with $200 \mu \mathrm{l}$ of binding buffer and further analyzed by flow cytometry using FACS Calibur (BD Biosciences). Data were analyzed by Cell Quest software that a region with less cell debris to calculate the percentages of four quadrants and apoptosis rate\%=(Q2+Q4)/(Q2+Q4) x100\% $(46,47)$.

Measurement of caspase-3 activity. The commercially available caspase-3 colorimetric assay kit (Keygen Biotech, Nanjing, China) was employed to determine the activity of caspase-3. Lysates of HT-29 cells were prepared after treatment with $500 \mu \mathrm{g} / \mathrm{ml}$ acidic EPS fractions (47). Assays were performed by incubating $150 \mu \mathrm{l}$ of cell lysate per sample with $50 \mu \mathrm{l}$ of reaction buffers (including $0.5 \mu \mathrm{l}$ DTT) on 96-well microtiter plates. Then $5 \mu \mathrm{l}$ of caspase- 3 substrate was added into the samples and incubated at $37^{\circ} \mathrm{C}$ for $4 \mathrm{~h}$. The absorbance was measured at $405 \mathrm{~nm}$ to determine the caspase- 3 activity of the tested samples using a microplate reader. Detailed data analyses process was performed according to the manufacturer's recommendation.

Statistical analysis. All data were expressed as mean \pm standard deviation (SD) of three replicates $(\bar{x} \pm S D, n=3)$. Tests of significant differences were determined by one-way ANOVA by SPSS 20.0 (IBM Corp., Armonk, NY, USA ). Duncan's and LSD's multiple range tests were used to determine differences among groups. $\mathrm{P}<0.05$ was considered to indicate a statistically significantly differenence.

\section{Results}

Screening of Lactobacillus strains for anti-proliferation effects by MTT assay. A comparative analysis of proliferation inhibition on HT-29 cells by extracellular polymeric substances, which were produced by 9 Lactobacillus strains and one reference strain LGG, respectively, was presented in Table I. The results indicated that 3 Lactobacillus strains, L. casei M5, L. casei SB27 and L. casei X12, exerted the most robust anti-proliferation activity, which were significantly higher than LGG reference strain $(\mathrm{P}<0.01)$. The extracellular 

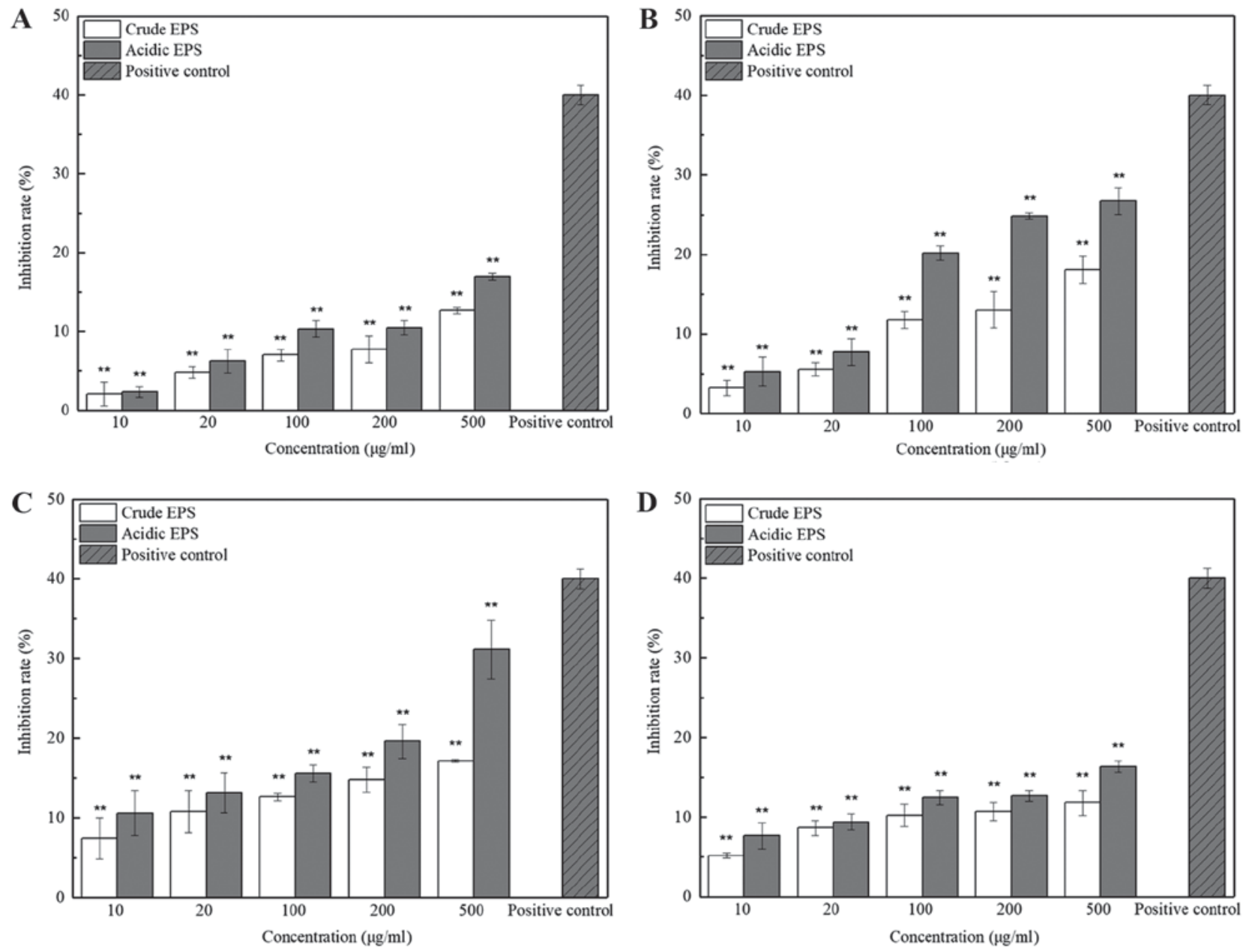

Figure 1. Anti-proliferation effect of crude and acidic EPS produced by (A) L. casei K11, (B) L. casei M5, (C) L. casei SB27 and (D) L. casei X12 on HT-29 cells. The negative control group was the absorbance of the system without the addition of EPS. The positive control group was the absorbance of the system treated with $5 \mu \mathrm{g} / \mathrm{ml}$ daunorubicin. ${ }^{* *} \mathrm{P}<0.01$ vs. the positive control group. EPS, exopolysaccharides.

polymeric substances from $L$. casei K11 also showed significant higher anti-proliferation activities compared with that of the LGG strain $(\mathrm{P}<0.05)$. The extracellular polymeric substances produced by other 5 strains, however, presented moderate anti-proliferation activity on HT-29 cells. Thus, we identified 4 of 9 tested strains presented a significant higher inhibitory effect upon HT-29 cellular proliferation.

In vitro anti-proliferation activity of crude and acidic EPS on HT-29 cells. The anti-proliferation effect of crude and acidic EPS produced by L. casei K11, L. casei M5, L. casei SB27 and L casei X12 on HT-29 cells was determined by MTT assay under 5 different concentrations. As shown in Fig. 1(c), the inhibition effect of both crude and acidic EPS produced by $L$. casei SB27 on HT-29 cells significantly increased along with the increased concentrations $(\mathrm{P}<0.01)$. Inhibition of the crude and acidic EPS produced by other 3 strains showed same trend but with less effect. These results indicated the dose-dependent inhibition effects of EPS on HT-29 cells. In addition, the anti-proliferation activities of the acidic EPS group was higher than that of the crude EPS group, especially at higher concentration. Since $500 \mu \mathrm{g} / \mathrm{ml}$ EPS showed the highest inhibition rate on HT-29 cells, especially in that of $L$. casei SB27, subsequent experiments were conducted with EPS at this concentration further tested. The inhibition rate of $500 \mu \mathrm{g} / \mathrm{ml}$ acidic EPS from K11 M5, SB27, and X12 strain in Vero cell line was $1.02 \pm 0.71,4.20 \pm 0.77,2.38 \pm 1.37$, and $4.76 \pm 0.93 \%$, respectively, which implied that the EPS was non-toxic for normal cells. This concentration was accordingly selected for subsequent experiments.

Effects of crude and acidic EPS on cell division cycle. Excessive proliferation is well known as one of the most salient characteristics of cancer cells. Therefore, any agent by which cancer cell cycles can be arrested represents an effective anticancer substance. The effects of crude and acidic EPS from 4 L. case $i$ strains on the HT-29 cell cycle phase distribution was examined by flow cytometry (Fig. 2). The percentage of $G_{0} / G_{1}$ phase increased significantly $(\mathrm{P}<0.01)$ when HT-29 cells were incubated with crude and acidic for $48 \mathrm{~h}$, while the percentage of cells at $\mathrm{G}_{2}$ and $\mathrm{S}$ phases decreased. L. casei $\mathrm{K} 11$ crude EPS group were the exception, whose cell percentage at the $S$ phase increased compared with control but cell percentage of the $\mathrm{G}_{2}$ phase was with a sharp decrease $(\mathrm{P}<0.01)$. In addition, acidic EPS group gained more percentage of cells at the $G_{0} / G_{1}$ phase compared with crude EPS group. Specially, maximal increase (from 71.93 to $81.93 \%$ ) of HT-29 cell percentage at the $G_{0} / G_{1}$ phase was observed in L. casei SB27 acidic EPS group. 

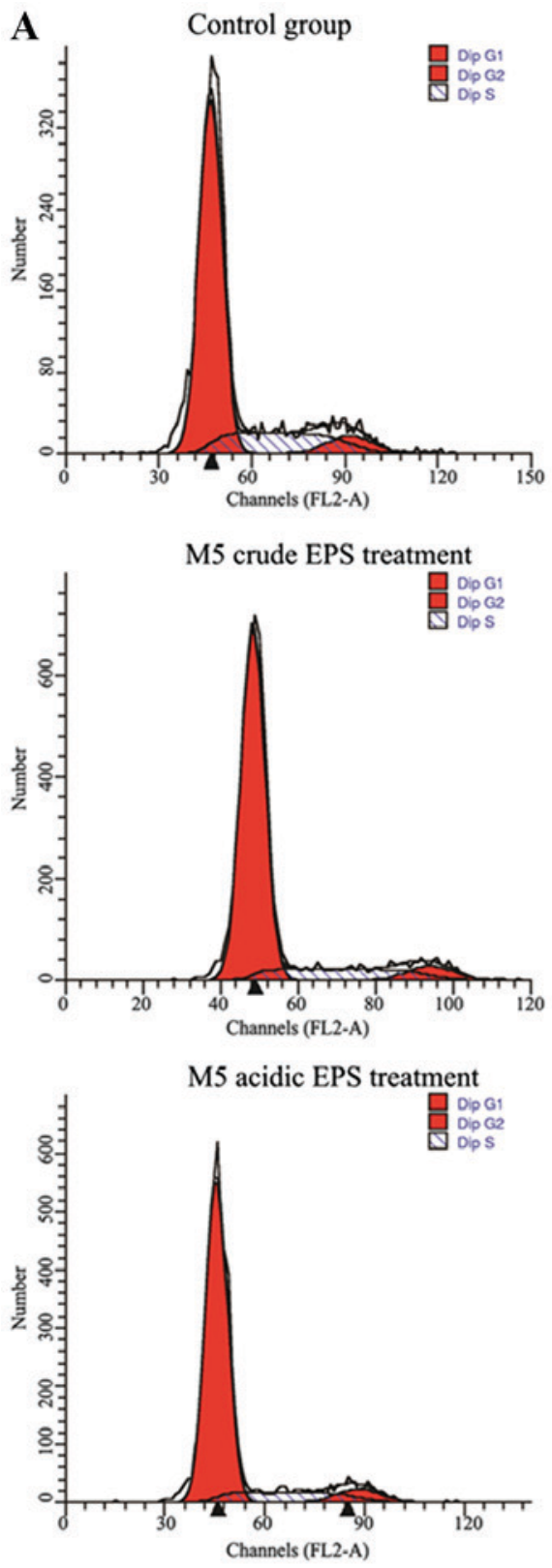
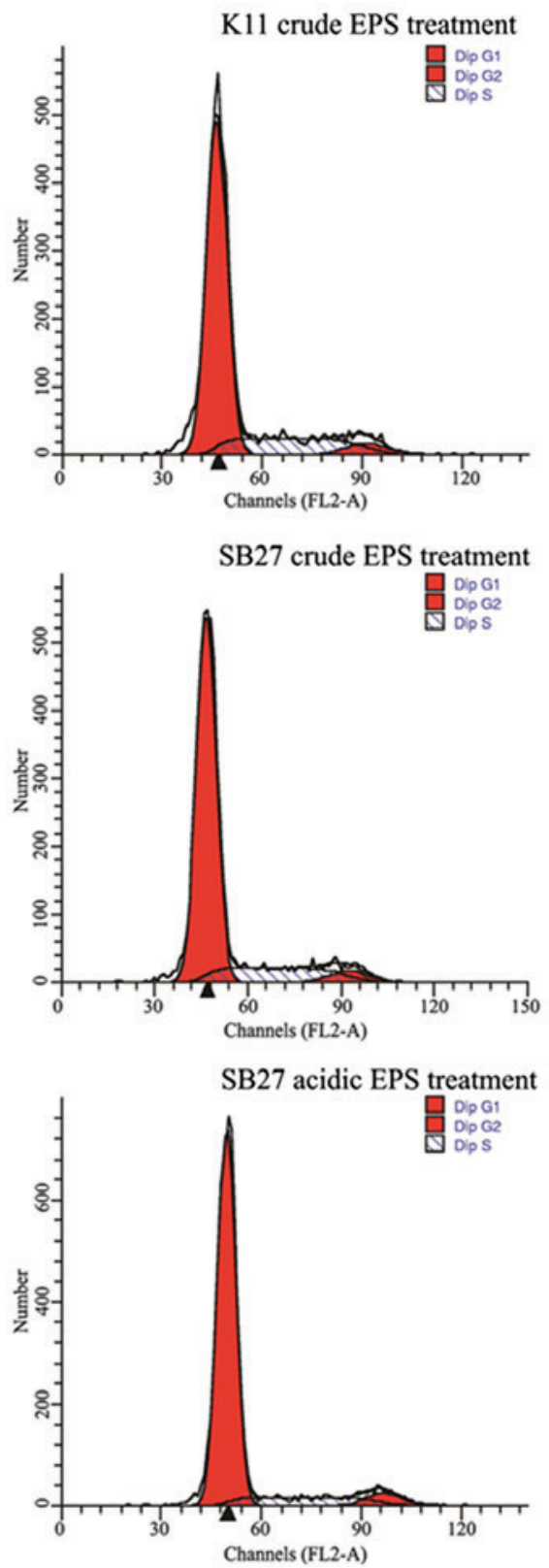

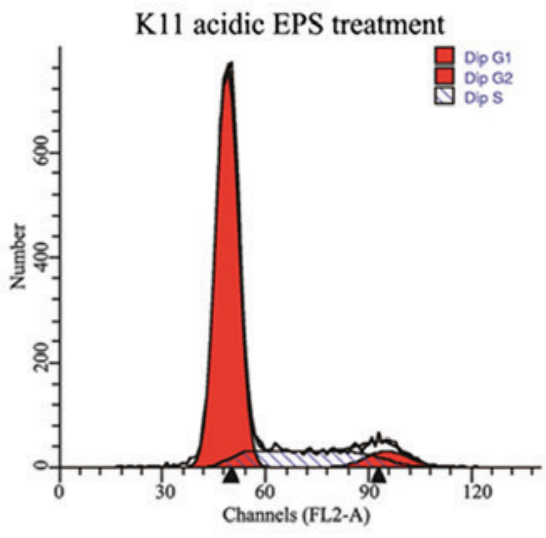

$\mathrm{X} 12$ crude EPS treatment

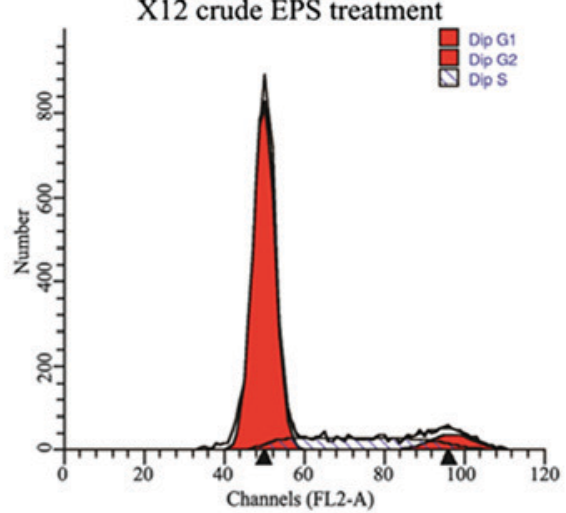

X12 acidic EPS treatment

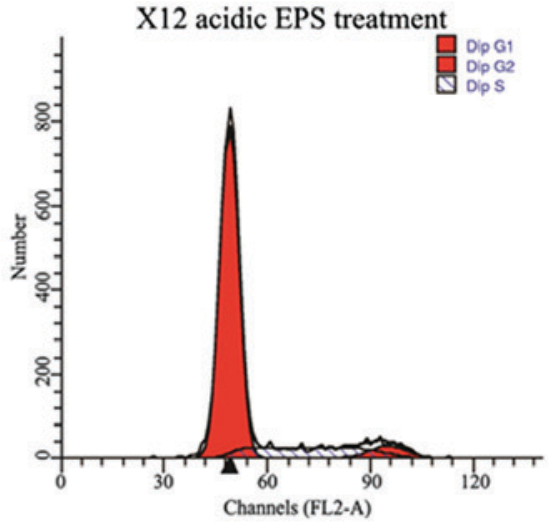

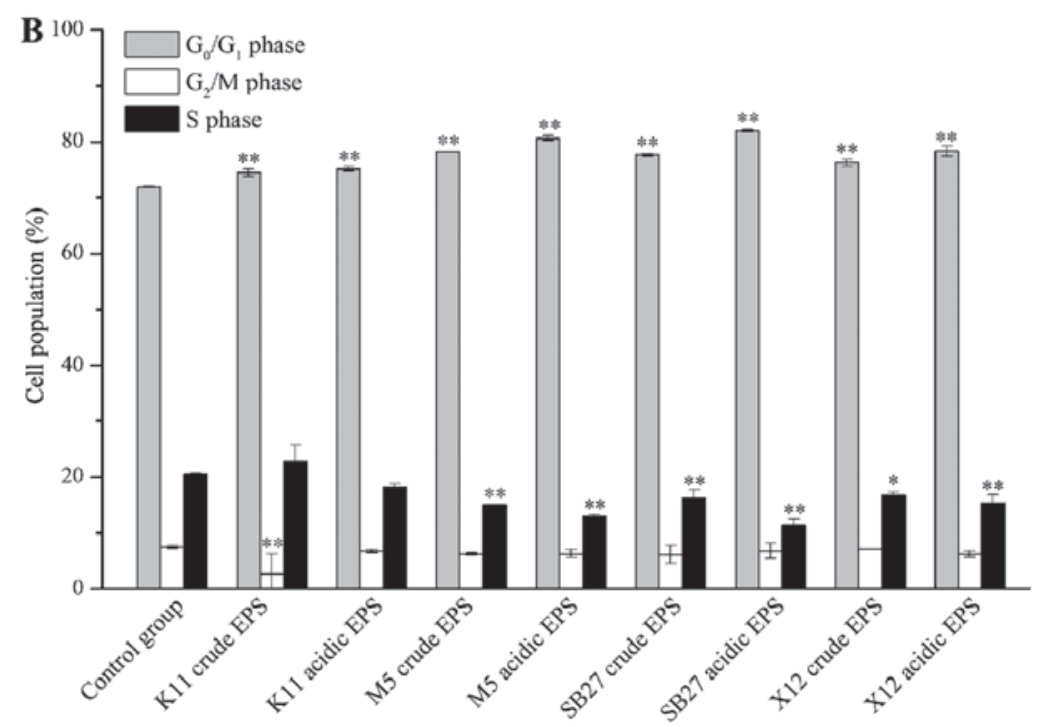

Figure 2. Effects of crude and acidic EPS on the cell cycle progression of HT-29 cells. (A) Representative histograms depicting cell cycle distribution in HT-29 cells treated with $500 \mu \mathrm{g} / \mathrm{ml}$ crude or acidic EPS. (B) Column statistics depicting cell cycle distribution in HT-29 cells treated with crude or acidic EPS. ${ }^{*} \mathrm{P}<0.05$ and ${ }^{* *} \mathrm{P}<0.01$ vs. the control group. EPS, exopolysaccharides. 
Effects of crude and acidic EPS on HT-29 cell apoptosis by flow cytometry. Annexin V-FITC and PI staining method was employed and apoptosis analyses were performed to evaluate the apoptosis induction effect of EPS on HT-29 cells. As illustrated in Fig. 3, the four L. casei strains induced HT-29 cell apoptosis to different levels compared to the untreated control cells. Acidic EPS induced a higher apoptosis rate on HT-29 cells than crude EPS, which was consistent with the effect on anti-proliferation. Significant induction of apoptosis was observed in HT-29 cells after treatment with EPS either from L. casei SB27 or L. casei M5, whereas only mild apoptosis was triggered by $L$. casei X12. For $L$. casei K11, its acidic EPS induced a moderate apoptosis on HT-29 cells while crude EPS did not show significant effects on induction of apoptosis.

Acidic EPS induced nuclei morphological changes in HT-29 cell. Hoechst staining was conducted to further appraise the apoptosis of HT-29 cells treated with acidic EPS. As shown in Fig. 4A, EPS-untreated cells appeared circular or elliptical, with no condensation of the nucleus being presented. In contrast, cells treated with acidic EPS produced by 4 kinds of $L$. case $i$ strains showed different degrees of morphological changes within nucleus and markedly condensed dots known as apoptotic bodies. Furthermore, cells treated with acidic L. casei SB27 EPS exhibited the most obvious morphological changes when subjected to Hoechst 33258 staining (Fig. 4D). Overall, based on the results of nuclei morphological changes, acid EPS group indeed induced HT-29 colon cancer cell apoptosis.

Effects of acidic EPS treatment on activity of caspase-3. HT-29 cells treated with acidic EPS were subjected to caspase-3 activity assay. A statistically increase in the ratio of absorbance over that of controls was obtained (Fig. 5), which revealed that all 4 kinds of tested EPS were able to activate caspase-3. The maximal increase of caspase- 3 activation was observed in HT-29 colon cancer cells treated with $L$. casei SB27 acidic EPS, while the minimal increase of caspase-3 activation was observed in $L$. case $i \mathrm{~K} 11$ acidic EPS group. The results indicated that $L$. casei SB27 acidic EPS was more effective in activating caspase-3, which was consistent with its effect on inducing apoptosis.

\section{Discussion}

Colon cancer is one of the most notorious malignant tumors with high incidence and mortality. Chemotherapy is one of the most commonly used therapeutic modalities for the treatment of cancer, but most anticancer drugs currently used in chemotherapy are cytotoxic to normal cells, resulting in multiple-organ toxicity such as hemopoetic suppression and immunotoxicity (18). Polysaccharides from natural sources are recently found as effective, relatively nontoxic substance with a wide range of biological activities and accordingly have attracted lots of attention (48). It suggested that the polysaccharides with antitumor property can be used as one ideal substitute for tumor therapy. The present study evaluated the effects of EPS from nine previously reported Lactobacillus strains with high degree of bio-activity on HT-29 cells which were used in several studies of antitumor activity of EPS $(36,38)$

We identified $4 L$. casei strains, including $L$. casei $\mathrm{M} 5$, L casei $\mathrm{SB} 27$, L. casei $\mathrm{X} 12$, and $L$. casei $\mathrm{K} 11$, having a significant inhibitory effect on HT-29 cell proliferation, whereas the rest 5 strains presented poor anti-proliferation effects. Subsequent MTT assay of purified EPS from these four strains further verified their anti-proliferation effects on HT-29 cells but nontoxic to Vero cells, a normal cell. Since the inhibition rate of EPS in cancer cells was less than that of clinical drugs, the inhibition was considered to be effective when the rate was $>20 \%$ by using $100 \mu \mathrm{g} / \mathrm{ml}$ EPS $(17,36)$. While the inhibition effect of EPS produced by $L$. casei SB27 on HT-29 cells significantly increased along with the increased concentrations $(\mathrm{P}<0.01)$, acidic EPS produced by $L$. casei M5 showed a inhibition rate close to $20 \%$ at a concentration of $100 \mu \mathrm{g} / \mathrm{ml}$. The inhibition effect of produced EPS on HT-29 cells varied from strain to strain, although these nine Lactobacillus strains belong to the same genus. Our results were consistent with previous report that EPS isolated from different strains showed clear differences in their characteristics and biological activities (49), which may be attributed to the genetic differences of the strains.

Cell proliferation is tightly regulated by the cell cycle: $\mathrm{S}$ phase for DNA synthesis, M phase for mitosis, G0/G1 and $\mathrm{G} 2$ phase. The G1/S transition is a vital checkpoint in the progress of cell cycle and responsible for the initiation and completion of DNA replication (50). By using FACS analyses we observed that the inhibitory effect of crude and acidic EPS on HT-29 cell proliferation was related to the prevention of G1 to $\mathrm{S}$ transition.

Cell shrinkage, nuclear fragmentation, and chromatin condensation are included in a series of typical morphological features of apoptosis (51). Both flow cytometry and hoechst staining showed the apoptotic evidence of EPS on HT-29 cells. Caspase- 3 is initially formed as a $32 \mathrm{kDa}$ zymogen and cleaved into 17 and $12 \mathrm{kDa}$ subunits when it was activated in the apoptotic cell both by extrinsic (death ligand) and intrinsic (mitochondrial) pathways. Activation of caspase-3 is often the signal to ensure that the cellular components are degraded in a controlled manner, carrying out cell death with minimal effect on surrounding tissues (52). The increased caspase-3 activity indicated the apoptosis induced in HT-29 colon cancer cells by acidic ESPs were, in part, mediated by a caspase-dependent pathway. In the near future, it would be interesting to further study the molecular events of cell apoptosis under the treatment of EPS.

An interesting finding in the present study is that acidic EPS has stronger effect of anti-proliferation and apoptosis on HT-29 cell than crude EPS. Coincidentally, Zhang et al compared the antitumor activity of neutral vs. acidic polysaccharides isolated and purified from the dried bulbs of Allium macrostemon Bunge against human gastric carcinoma cells BGC-823 and found that acidic polysaccharides showed significantly higher inhibition rate than neutral polysaccharides (53). This phenomenon might be attributed to differences between crude and acidic EPS in composition and structure characteristics. In this study, the obtained crude EPS were mixtures of acidic polysaccharides and proteins, while the acidic EPS primarily consisted of 


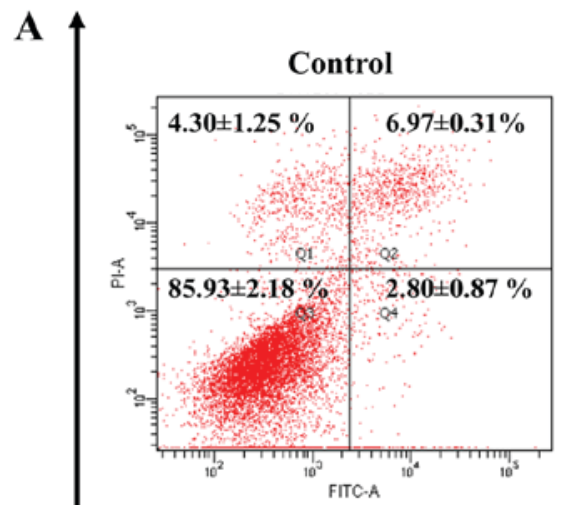

Crude M5-EPS

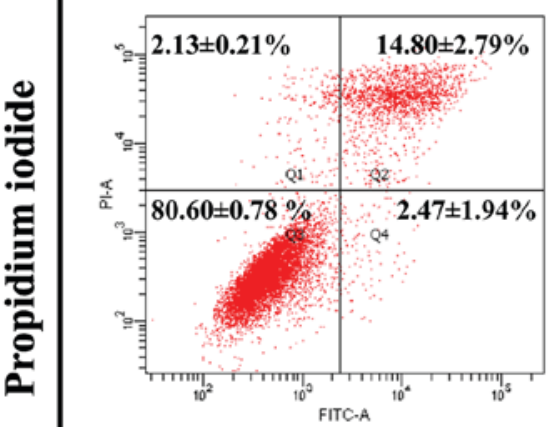

Acidic M5-EPS

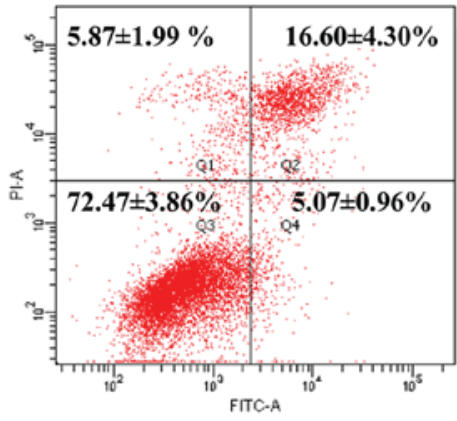

Crude K11-EPS

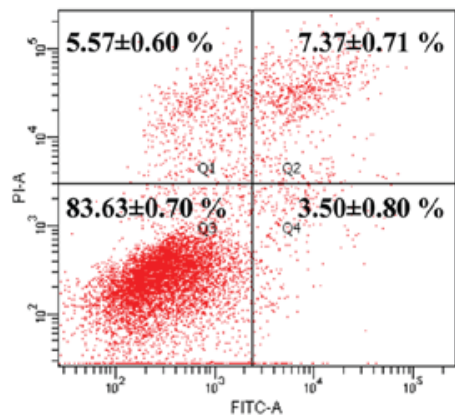

Crude SB27-EPS

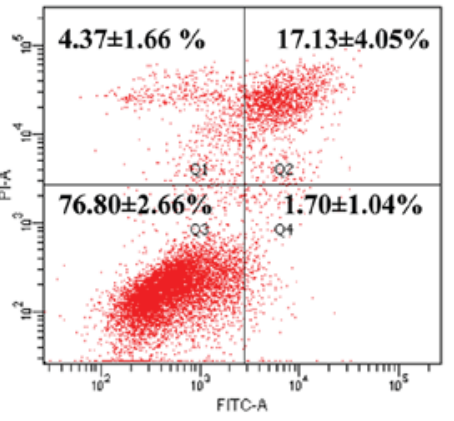

Acidic SB27-EPS
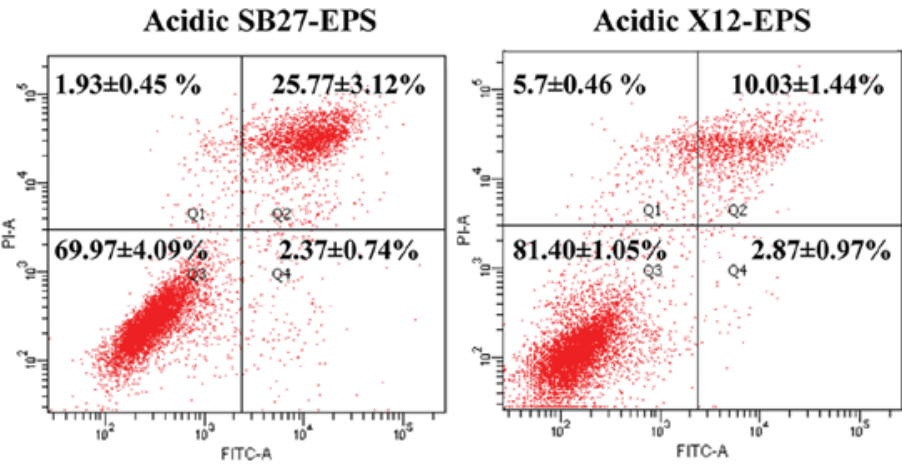

Acidic K11-EPS

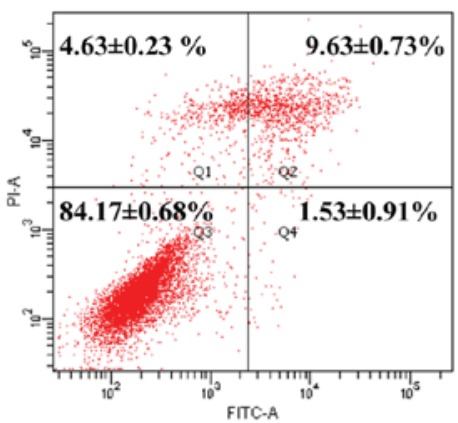

Crude X12-EPS

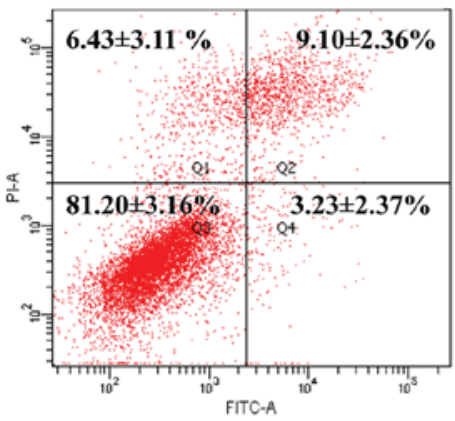

Acidic X12-EPS

\section{Annexin V-FITC}



Figure 3. (A) Flow cytometry analysis with Annexin V-FITC/PI. Cells treated with medium were used as the control. (B) The flow cyometry results were statistically analysed. ${ }^{*} \mathrm{P}<0.05$ and ${ }^{* *} \mathrm{P}<0.01$ vs. the control group. PI, propidium iodide; FITC, Fluorescein isothiocyanate; EPS, exopolysaccharides. 

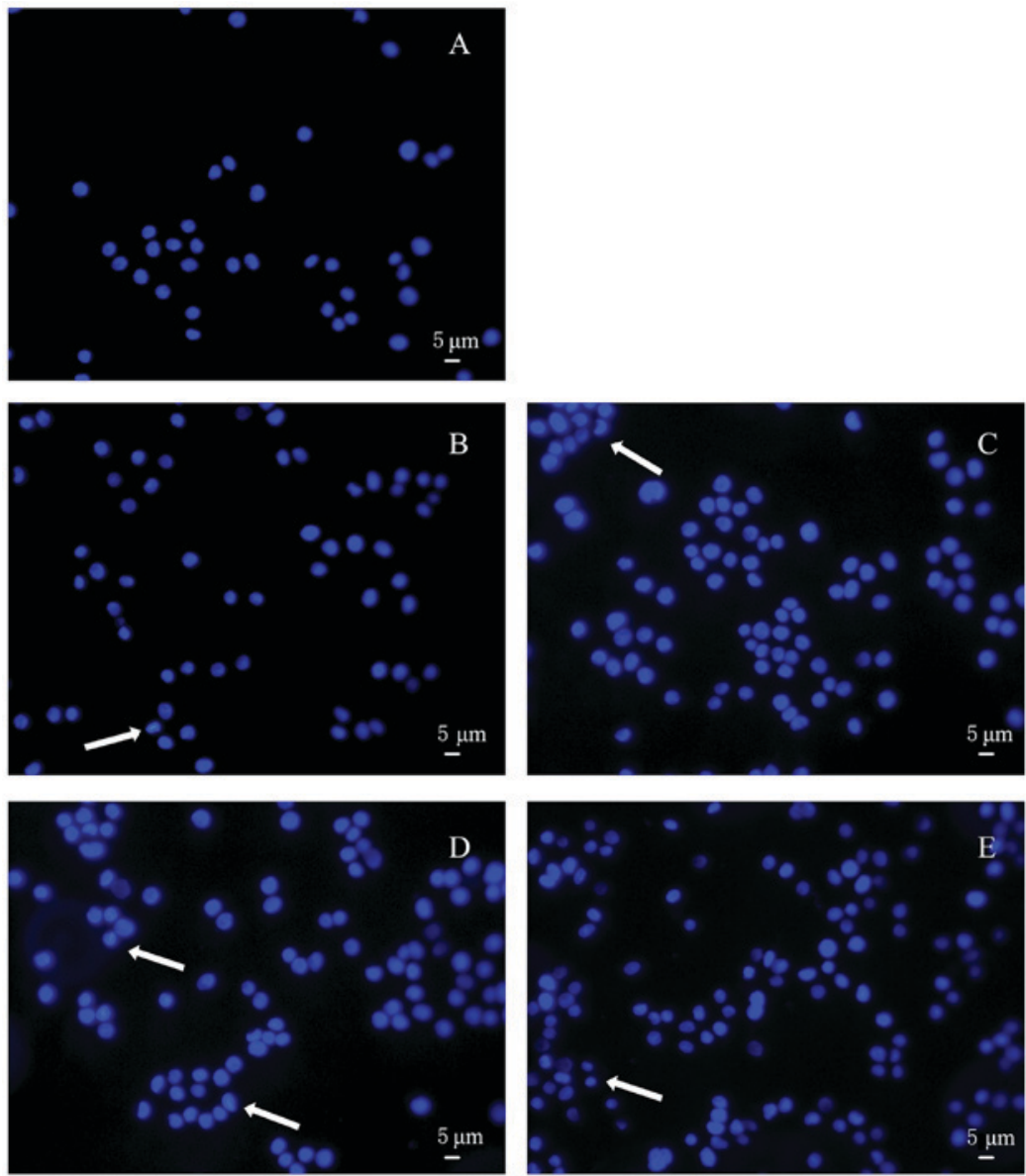

Figure 4. Hoechst staining of HT-29 cells either untreated or treated with acidic EPS for $48 \mathrm{~h}$. The blue fluorescence marks the nucleus of HT-29 cells and the white arrows indicate apoptotic or dead cells. (A) HT-29 cells un-treated with acidic EPS; (B) HT-29 cells treated with acidic EPS from K11; (C) HT-29 cells treated with acidic EPS from M5; (D) HT-29 cells treated with acidic EPS from SB27; (E) HT-29 cells treated with acidic EPS from X12. EPS, exopolysaccharides.

acidic polysaccharides with trace proteins. In our previous study, two high molecular weight fractions (LW1 and LW2) were identified in EPS from $L$ casei SB27 and showed a sheet-like appearance with a folded surface and a compact structure (54). We will continue to determine the structural characteristics of the acidic EPS to further understand the key factors affecting its activity.

There were some limitations of our study. The effect of $500 \mathrm{ug} / \mathrm{ml}$ EPS was only tested on HT-29 cells. It is unclear whether the EPS identified in present study has effects on other cancer cell lines. Meanwhile, this concentration is relatively high and expected to be toxic when used in human. The toxicity of EPS was tested on Vero cell line in consideration of its extensive usage in researches of various types of biological pharmaceuticals (55) and little effect on its proliferation was found, which was consistent to reports from other group (56). However, in order to evaluate its safety, it is necessary to test the toxicity of EPS on normal human colon cells and human in vivo. We are planning to do this after elucidating the mechanism of antitumor activity of EPS. Furthermore, previous reports showed the immunologic reaction elicited by the EPS, such as increased expression of TNF- $\alpha$, IL-10, and IL-1 $\beta$ (57-59). Whether the EPS from the 9 Lactobacillus strains has immunomodulatory activity on cells and human being is unknown.

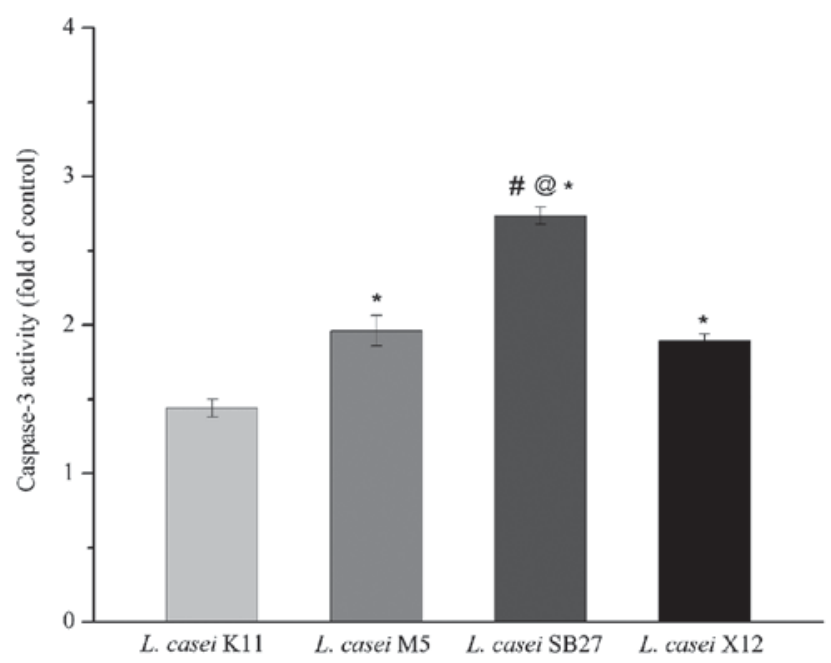

Figure 5. Caspase-3 activity in HT-29 cells following $48 \mathrm{~h}$ treatment with acidic EPS. The differences between groups was determined by one-way ANOVA with Duncan's post hoc test. " $\mathrm{P}<0.05$ vs. the $L$. casai $\mathrm{K} 11$ group; ${ }^{\text {"}} \mathrm{P}<0.05$ vs. the $L$. casai $\mathrm{M} 5$ group; ${ }^{\circledR} \mathrm{P}<0.05$ vs. the $L$. casai $\mathrm{X} 12$ group. EPS, exopolysaccharides

In conclusion, the results of present study suggest that EPS from L. casei M5, L. casei SB27, L. casei X12, and L. casei K11, especially acidic EPS produced by $L$. case $i$ SB27, exerted 
significant anti-proliferation effect on HT-29 cells via the induction of G0/G1 cell cycle arrest and caspase-3-dependent apoptosis. In the future, it is necessary to detect whether the EPS has broad spectrum antitumor activity on other cancer cell lines and immunomodulatory activity in order to help us to evaluate the clinical implications and safety of EPS.

\section{Acknowledgements}

Not applicable.

\section{Funding}

The present study was financially supported by the program of Harbin outstanding academic leaders (grant no. 2014RFXXJ026), the National Natural Science Foundation of China (grant no. 31271906/C200204) and the National Natural Science Foundation of China (grant no. 31301515).

\section{Availability of data and materials}

All data generated or analyzed during this study are included in this published article.

\section{Authors' contributions}

WD performed the experiments and wrote the manuscript. LZ and XH contributed to the conception of the study and revised the manuscript. HY performed the data analyses and revised the manuscript. $\mathrm{XH}$ reviewed and polished the manuscript. YZ helped perform the analysis. LX performed the data analyses and all authors approved the final version of the manuscript.

\section{Ethics approval and consent to participate}

Not applicable.

\section{Patient consent for publication}

Not applicable.

\section{Conflict of interests}

The authors declare that they have no competing interests.

\section{References}

1. Jemal A, Bray F, Center MM, Ferlay J, Ward E and Forman D: Global cancer statistics. CA Cancer J Clin 61: 69-90, 2011.

2. Fotiadis CI, Stoidis CN, Spyropoulos BG and Zografos ED: Role of probiotics, prebiotics and synbiotics in chemoprevention for colorectal cancer. World J Gastroenterol 14: 6453-6457, 2008.

3. Commane D, Hughes R, Shortt C and Rowland I: The potential mechanisms involved in the anti-carcinogenic action of probiotics. Mutat Res 591: 276-289, 2005.

4. Wong YN, Chang WC, Clapper M and Engstrom PF: Chemoprevention of colorectal cancer, in: L.B. Saltz (eds), Colorectal Cancer: Evidence-Based Chemotherapy Strategies, Humana Press Inc., Totowa, NJ: pp33-49, 2006.

5. Wollowski I, Rechkemmer G and Pool-Zobel BL: Protective role of probiotics and prebiotics in colon cancer. Am J Clin Nutr 73 (2 Suppl): 451S-455S, 2001.
6. Aachary AA, Gobinath D, Srinivasan K and Prapulla SG: Protective effect of xylooligosaccharide from corncob on 1,2-dimethylhydrazine induced colon cancer in rats. Bioact Carbohydr Dietary Fibre 5: 146-152, 2015.

7. Huang L, Shan YJ, He CX, Ren MH, Tian PJ and Song W: Effects of L. paracasei subp. paracasei X12 on cell cycle of colon cancer HT-29 cells and regulation of mTOR signalling pathway. J Funct Foods 21: 431-439, 2016.

8. Chan AT and Giovannucci EL: Primary prevention of colorectal cancer. Gastroenterology 138: 2029-2043, 2010.

9. García-Ruiz A, Llano DGD, Esteban-Fernández A, Requena T, Bartolomé B and Moreno-Arribas MV: Assessment of probiotic properties in lactic acid bacteria isolated from wine. Food Microbiol 44: 220-225, 2014.

10. Gonet AK, Strus M and Heczko PB: P1250 Influence of Lactobacilli probiotic strains on apoptosis of colon cancer cells lines. Int J Antimicrob Agents 29 (2 Suppl): S343-S344, 2007.

11. Hu P, Song W, Shan Y, Du M, Huang M, Song C and Zhang L: Lactobacillus paracasei subsp. paracasei M5L induces cell cycle arrest and calreticulin translocation via the generation of reactive oxygen species in HT-29 cell apoptosis. Food Function 6: 2257-2265, 2015.

12. Laiño J, Villena $J$, Kanmani $P$ and Kitazawa HL: Immunoregulatory effects triggered by lactic acid bacteria exopolysaccharides: New insights into molecular interactions with host cells. Microorganisms 4: E27, 2016.

13. Ruas-Madiedo P, Hugenholtz J and Zoon PL: An overview of the functionality of exopolysaccharides produced by lactic acid bacteria. Int Dairy J 12: 163-171, 2002.

14. Górska-Frączek S, Sandström C, Kenne L, Paściak M, Brzozowska E, Strus M, Heczko P and Gamian A: The structure and immunoreactivity of exopolysaccharide isolated from Lactobacillus johnsonii strain 151. Carbohydr Res 378: 148-153, 2013.

15. Chen Z, Shi J, Yang X, Nan B, Liu Y and Wang Z: Chemical and physical characteristics and antioxidant activities of the exopolysaccharide produced by Tibetan kefir grains during milk fermentation. Int Dairy J 43: 15-21, 2015.

16. Ai LZ, Zhang H, Guo BH, Chen W, Wu ZJ and Wu Y: Preparation, partial characterization and bioactivity of exopolysaccharides from Lactobacillus casei LC2W. Carbohydr Polym 74: 353-357, 2008.

17. Liu CT, Chu FJ, Chou CC and Yu RC: Antiproliferative and anticytotoxic effects of cell fractions and exopolysaccharides from Lactobacillus casei 01. Mutat Res 721: 157-162, 2011.

18. Ehrke MJ: Immunomodulation in cancer therapeutics. Int Immunopharmacol 3: 1105-1119, 2003.

19. Yang Z, Xu J, Fu Q, Fu X, Shu T, Bi Y and Song B: Antitumor activity of a polysaccharide from Pleurotus eryngii on mice bearing renal cancer. Carbohydr Polym 95: 615-620, 2013.

20. Deepak V, Ramachandran S, Balahmar RM, Pandian SR, Sivasubramaniam SD, Nellaiah $\mathrm{H}$ and Sundar K: In vitro evaluation of anticancer properties of exopolysaccharides from Lactobacillus acidophilus in colon cancer cell lines. In Vitro Cell Dev Biol Anim 52: 163-173, 2016.

21. Marta CL, Bernadeta N, Malgorzata S, Maria W, Sabina GF, Andrzej G and Janusz M: Further studies on immunomodulatory effects of exopolysaccharide isolated from Lactobacillus rhamnosus KL37C. Cent Eur J Immunol 38: 1270-1271, 2013.

22. Li JY, Jin MM, Meng J, Gao SM and Lu RR: Exopolysaccharide from Lactobacillus planterum LP6: Antioxidation and the effect on oxidative stress. Carbohydr Polym 98: 1147-1152, 2013.

23. Collins MD, Phillips BA and Zanoni P: Deoxyribonucleic Acid Homology Studies of Lactobacillus casei, Lactobacillus paracasei sp. nov., subsp. paracasei and subsp. tolerans and Lactobacillus rhamnosus sp. nov., comb. nov. Int J Syst Bacteriol 39: 105-108, 1989.

24. Ortu S, Felis GE, Marzotto M, Deriu A, Molicotti P, Sechi LA, Dellaglio F and Zanetti S: Identification and functional characterization of Lactobacillus strains isolated from milk and Gioddu, a traditional Sardinian fermented milk. Int Dairy J 17: 1312-1320, 2007.

25. Wang SM, Zhang LW, Fan RB, Han X, Yi HX, Zhang LL, Xue CH, Li HB, Zhang YH and Shigwedha N: Induction of HT-29 cells apoptosis by lactobacilli isolated from fermented products. Res Microbiol 165: 202-214, 2014.

26. Zhang YC, Zhang LW, Tuo YF, Guo CF, Yi HX, Li JY, Han X and Du M: Inhibition of Shigella sonnei adherence to HT-29 cells by lactobacilli from Chinese fermented food and preliminary characterization of S-layer protein involvement. Res Microbiol 161: 667-672, 2010. 
27. Wang S, Han X, Zhang L, Zhang Y, Li H and Jiao Y: Whole peptidoglycan extracts from the lactobacillus paracasei subsp. Paracasei M5 strain exert anticancer activity in vitro. Biomed Res Int 2018: 2871710, 2018.

28. Tuo YF, Zhang LW, Yi HX, Zhang YC, Zhang WQ, Han X, Du M, Jiao YH and Wang SM: Short communication: Antiproliferative effect of wild Lactobacillus strains isolated from fermented foods on HT-29 cells. J Dairy Sci 93: 2362-2366, 2010.

29. Saxelin M: Lactobacillus GG-A human probiotic strain with thorough clinical documentation. Food Rev Int 13: 293e313, 1997.

30. Caro SD, Tao H, Grillo A, Elia C, Gasbarrini G, Sepulveda AR and Gasbarrini A: Effects of Lactobacillus GG on genes expression pattern in small bowel mucosa. Dig Liver Dis 37: 320-329, 2005.

31. Ai LZ, Zhang H, Guo BH, Chen W, Wu ZJ and Tang J: Optimization of culture conditions for exopolysaccharide production by Lactobacillus casei LC2W. Milchwissenschaft-milk Sci Int 61: 374-377, 2006.

32. Ramos AN, Gobbato N, Rachid M, Gonzalez L, Yantorno O and Valdez JC: Effect of Lactobacillus plantarum and Pseudomonas aeruginosa culture supernatants on polymorphonuclear damage and inflammatory response. Int Immunopharmacol 10: 247-251, 2010.

33. Choi SS, Kim Y, Han KS, You S, Oh S and Kim SH: Effects of Lactobacillus strains on cancer cell proliferation and oxidative stress in vitro. Lett Appl Microbiol 42: 452-458, 2006.

34. Liu Z, Zhang Z, Qiu L, Zhang F, Xu X, Wei H and Tao X: Characterization and bioactivities of the exopolysaccharide from a probiotic strain of Lactobacillus plantarum WLPL04. J Dairy Sci 100: 6895-6905, 2017.

35. Wang K, Li W, Rui X, Chen X, Jiang $M$ and Dong $M$ : Characterization of a novel exopolysaccharide with antitumor activity from Lactobacillus plantarum 70810. Int J Biol Macromol 63: 133-139, 2014.

36. Wang J, Zhao X, Yang Y, Zhao A and Yang Z: Characterization and bioactivities of an exopolysaccharide produced by lactobacillus plantarum Yw32. Int J Biol Macromol 74: 119-126, 2015.

37. Stefano DD, Tommonaro G, Simeon V, Poli A, Nicolaus B and Carnuccio R: A polysaccharide from tomato (Lycopersicon Esculentum) peels affects Nf-kb activation in Lps-stimulated J774 macrophages. J Nat Prod 70: 1636-1639, 2007.

38. Park S Y, Kim E J, Shin H K, Kwon DY, Kim MS, Surh YJ and Park JH: Induction of apoptosis in Ht-29 colon cancer cells by phloretin. J Med Food 10: 581-586, 2007

39. Lin R, Liu H, Wu S, Pang L, Jia M, Fan K, Jia S and Jia L: Production and in vitro antioxidant activity of exopolysaccharide by a mutant, Cordyceps militaris SU5-08. Int J Biol Macromol 51: 153-157, 2012

40. DuBois M, Gilles KA, Hamilton JK, Rebers PA and Smith F: Colorimetric Method for Determination of Sugars and Related Substances. Analytical Chemistry 28: 350-356, 1956.

41. Wang X, Wang S, Li Y, Wang F, Yang X and Yao J: Sulfated Astragalus polysaccharide can regulate the inflammatory reaction induced by LPS in Caco2 cells. Int J Biol Macromol 60: 248-252, 2013

42. Liu H, Xiao Y, Xiong C, Wei A and Ruan J: Apoptosis induced by a new flavonoid in human hepatoma HepG2 cells involves reactive oxygen species-mediated mitochondrial dysfunction and MAPK activation. Eur J Pharmacol 654: 209-216, 2011.

43. Choi HJ, Lim Do Y and Park JH: Induction of G1 and G2/M cell cycle arrests by the dietary compound 3,3'-diindolylmethane in ht-29 human colon cancer cells. BMC Gastroenterol 9: 1-11, 2009.

44. Shang LH, Li CM, Yang ZY, Che DH, Cao JY and Yu Y: Luffa echinata roxb. induces human colon cancer cell (Ht-29) death by triggering the mitochondrial apoptosis pathway. Molecules 17 : $5780-5794,2012$.
45. Sharma S, Singh RL and Kakkar P: Modulation of Bax/Bcl-2 and caspases by probiotics during acetaminophen induced apoptosis in primary hepatocytes. Food Chemical Toxicol 49: 770-779, 2011.

46. Huang T, Lin J, Cao J, Zhang P, Bai Y, Chen G and Chen K: An exopolysaccharide from trichoderma pseudokoningii and its apoptotic activity on human leukemia k562 cells. Carbohydr Polym 89: 701-708, 2012.

47. Liu Y,Zhang SP and Cai YQ: Cytoprotective effects of selenium on cadmium-induced LLC-PK1 cells apoptosis by activating JNK pathway. Toxicol In Vitro 21: 677-684, 2007.

48. Ooi VE and Liu F: Immunomodulation and anti-cancer activity of polysaccharide-protein complexes. Curr Med Chem 7: $715-729,2000$

49. Kanmani P, Satish kumar R, Yuvaraj N, Paari KA, Pattukumar V and Arul V: Production and purification of a novel exopolysaccharide from lactic acid bacterium Streptococcus phocae PI80 and its functional characteristics activity in vitro. Bioresour Technol 102: 4827-4833, 2011.

50. Nurse P: Ordering S phase and $M$ phase in the cell cycle. Cell 79: 547-550, 1994

51. Saraste A and Pulkki K: Morphologic and biochemical hallmarks of apoptosis. Cardiovasc Res 45: 528-537, 2000.

52. Jung MY, Kwon SK and Moon A: Chemopreventive allylthiopyridazine derivatives induce apoptosis in SK-Hep-1 hepatocarcinoma cells through a caspase-3-dependent mechanism. Eur J Cancer 37: 2104-2110, 2001.

53. Zhang Z, Wang F, Wang M, Ma L, Ye $\mathrm{H}$ and Zeng XA: Comparative study of the neutral and acidic polysaccharides from Allium macrostemon Bunge. Carbohydr Polym 117: 980-987, 2015.

54. Di W, Zhang L, Wang S, Yi H, Han X, Fan R and Zhang Y. Physicochemical characterization and antitumour activity of exopolysaccharides produced by Lactobacillus casei SB27 from yak milk. Carbohydr Polym 171: 307-315, 2017.

55. Osada N, Kohara A, Yamaji T, Hirayama N, Kasai F, Sekizuka T, Kuroda M and Hanada K: The genome landscape of the african green monkey kidney-derived vero cell line. DNA Res 21: 673-683, 2014

56. Mukhopadhyay SK, Chatterjee S, Gauri SS, Das SS, Mishra A, Patra M, Ghosh AK, Das AK, Singh SM and Dey S: Isolation and characterization of extracellular polysaccharide Thelebolan produced by a newly isolated psychrophilic Antarctic fungus Thelebolus. Carbohydr Polym 104: 204-212, 2014.

57. López P, Monteserín DC, Gueimonde M de los Reyes-Gavilán CG, Margolles A, Suárez A and Ruas-Madiedo P: Exopolysaccharide-producing Bifidobacterium strains elicit different in vitro responses upon interaction with human cells. Food Res Int 46: 99-107, 2012.

58. Nikolic M, Lopez P, Strahinic I, Suarez A, Kojic M, Fernandez-Garcia M, Topisirovic L, Golic N and Ruas-Madiedo P: Characterisation of the exopolysaccharide (EPS)-producing Lactobacillus paraplantarum BGCG11 and its non-EPS producing derivative strains as potential probiotics. Int J Food Microbiol 158: 155-162, 2012.

59. Patten DA, Leivers S, Chadha MJ, Maqsood M, Humphreys PN, Laws AP and Collett A: The structure and immunomodulatory activity on intestinal epithelial cells of the EPSs isolated from Lactobacillus helveticus sp. Rosyjski and Lactobacillus acidophilus sp. 5e2. Carbohydr Res 384: 119-127, 2014.

This work is licensed under a Creative Commons Attribution-NonCommercial-NoDerivatives 4.0 International (CC BY-NC-ND 4.0) License. 